\title{
Know Your Counterparts: The Importance of Wording for Stakeholder Communication in Social Franchise Enterprises
}

\author{
Arne Bergfeld $^{1}$ (I) Carolin Plagmann $^{1} \cdot$ Eva Lutz $^{1}$
}

Accepted: 17 October 2020/Published online: 6 November 2020

(C) The Author(s) 2020

\begin{abstract}
Social enterprises pursue a dual mission: on the one hand, they strive for social purpose, while on the other, they try to achieve economic stability despite scarce resources. To achieve the dual mission, social enterprises avail themselves of both for-profit and non-profit institutional logics. Due to this combination of multiple institutional logics, such enterprises can be classified as hybrid organizations. This study focuses on these organizations and investigates tensions between social enterprises and various stakeholder groups caused by the use of commercial logics within the social sector. In particular, we examine the perception of commercial versus social welfare logics by various stakeholder groups, and investigate the effects on organizational communication. Our study is centered on social franchise enterprises. We use an exploratory qualitative research approach based on semistructured interviews with 21 social franchisors and social franchisees of seven social franchise enterprises. Our main results suggest that the use of commercial logics in the social sector tends to decrease the legitimacy of social franchise enterprises in the eyes of internal stakeholders, the general public, and various (but not all) external stakeholder groups. Many stakeholders of social franchise enterprises show a strong aversion to commercial logics,
\end{abstract}

Arne Bergfeld

arne.bergfeld@hhu.de

Carolin Plagmann

carolin.plagmann@hhu.de

Eva Lutz

eva.lutz@hhu.de

1 Department of Entrepreneurship and Finance, Heinrich Heine University Düsseldorf, Universitätsstraße 1, 40225 Düsseldorf, Germany and particularly to commercial terminology. Overall, we conclude that social franchise enterprises very consciously apply commercial and social welfare logics and use alternative terminology where necessary to retain legitimacy and prevent tensions.

Keywords Non-profit · Hybridity · Communication · Institutional logics $\cdot$ Social franchising $\cdot$ Legitimacy

\section{Introduction}

Social enterprises are characterized by " $[\ldots]$ the explicit aim to benefit the community or the creation of "social value," rather than the distribution of profit, [...]" (Defourny and Nyssens 2010a, b, p. 16). Nevertheless, just like their commercial counterparts, social enterprises need to generate resources to be reinvested in order to achieve economic stability, retain operations, and serve their chosen purpose (Carroll and Stater 2009; Defourny and Nyssens 2010a, 2017). Due to their social mission and resulting strategic inflexibility, however, social enterprises need to tap a different, wider set of financial instruments, and have fewer options of unrestricted capital. Oftentimes, they access a unique mix of resources from government-linked institutions as well as private parties (Austin et al. 2006; Defourny and Nyssens 2010b; Teasdale 2012). To accomplish their dual missions, they avail themselves of both for-profit and non-profit institutional logics, leading to the presence of multiple logics within a single organization (Besharov and Smith 2014).

Organizations that combine multiple institutional logics and organizational forms at their cores are referred to as hybrid organizations. Due to their combination of multiple institutional logics of both business and charity, social 
enterprises are classified in this way and represent a continuum of hybrid organizations (Battilana and Lee 2014; Dart 2004a; Defourny and Nyssens 2017; Pache and Santos 2013). Our study centers on social franchise enterprises that have adopted logics initially developed in commercial franchising enterprises to scale their social mission (Tracey and Jarvis 2007). Just like commercial franchisors, social franchisors provide guidelines and other services and support independent social franchisee units of the enterprise. The social franchisee has to pay a franchise fee; in return, it gains the right to use the social franchisor's concept. Thus, social franchise enterprises provide goods and services to meet social needs and use institutional logics to scale their impact and achieve economic stability and sustainability (Beckmann and Zeyen 2014; Volery and Hackl 2010).

Such enterprises face various issues due to their usage of both social welfare and commercial logics, which are considered incompatible with each other (Besharov and Smith 2014). In order to be legitimate and successful, social enterprises have to take into account the interests of stakeholders from both sectors, and of those with combined, or hybrid, backgrounds. Moreover, they have to demonstrate their social and economic competence simultaneously (Dacin et al. 2011). While social entrepreneurs often reportedly draw their legitimacy from a social morality (Parkinson and Howorth 2008), some of them (have had to) master how to tactically use commercial language in order to convince external stakeholders, such as potential funders of their entrepreneurial efficiency (Dey and Teasdale 2016). The combination of both logics creates internal and external tensions in social enterprises because satisfying institutional demands from the one side might require defying those from the other (Pache and Santos 2010). These tensions have been recognized in previous literature (Bull 2008; Dey and Teasdale 2016; Parkinson and Howorth 2008; Seanor and Meaton 2007), and have even been credited for adding part of the unique value to social enterprises (Grant 2014). The aim of our study is to investigate if and how these tensions materialize in the particular case of social franchise enterprises and their stakeholders in German-speaking Europe. Thereby, we aim to shed light on the associated challenges in this specific case of hybridity in social enterprises and to examine the effects of such tensions on the franchises themselves. More specifically, we set out to examine the following research questions:

(1) What is the impact of combined social welfare and commercial logics in hybrid organizations within social franchise enterprises, that is, for internal stakeholders like salaried staff and volunteers?

(2) What is the impact of combined social welfare and commercial logics in hybrid organizations on social franchise enterprises' relation to their external surroundings, that is, between them and their external stakeholders like the general public, beneficiaries, (prospective) social franchisees, local authorities, and funders?

(3) How does the perception of commercial versus social welfare logics by stakeholders of social franchise enterprises affect their stakeholder communication?

We use a qualitative approach based on semi-structured interviews with 21 partners at seven social franchises to gain in-depth insights into hybrid organizational structures. In order to triangulate our findings, we interview both social franchisors and social franchisees. In addition, we analyze the written social franchise contracts of the participating enterprises. After analyzing, coding, and categorizing the data, we develop a theoretical framework and present it in a set of six propositions. We find evidence that the utilization of commercial logics in a social enterprise creates several tensions.

Specifically, we find that an imbalance between social welfare and commercial logics within hybrid organizations promotes a lack of acceptance of commercial logics by internal stakeholders (the social franchisors' and social franchisees' staff) and increases the potential for internal tensions. Furthermore, we find that an information asymmetry between social enterprises and external stakeholders (the general public, beneficiaries, (prospective) social franchisees, local authorities, and funders) can promote a lack of acceptance of commercial logics by these stakeholders in our particular setting and, in turn, decrease the legitimacy of a social enterprise, thereby increasing the potential for external tensions. While that holds true for a majority of all stakeholders, there are exceptions. Some potential funders have reportedly reacted positively to commercial franchising logics. Overall, we conclude that the social franchise enterprises in our sample very consciously communicate with specific stakeholders and use commercial, social welfare, and alternative logics depending on their specific counterparts to prevent tensions.

Our study advances research on hybrid organizations in three ways. First, we contribute to the existing research on the hybrid organizational structure of social enterprises (Austin et al. 2006; Battilana and Dorado 2010; Battilana and Lee 2014; Doherty et al. 2014; Mair et al. 2015; Pache and Santos 2013). Our analysis suggests that the combination of social welfare and commercial logics in a socially-oriented hybrid organization like a social franchise enterprise can create several internal and external tensions due to imbalances in logic and information asymmetries.

Second, we contribute to the research on the legitimacy of social enterprises (Dart 2004b; Nicholls 2010; Pache and Santos 2010; Smith et al. 2013; Smith and Lewis 2011). Our findings suggest that the use of commercial logics can 
have a significant influence on the legitimacy of a social enterprise. In particular, distinct internal and external stakeholders' expectations that differ from the actual focus of the social enterprise decrease legitimacy.

Finally, we contribute to the scarce and emerging research on the specific practice of social franchising (Beckmann and Zeyen 2013; Kistruck et al. 2011; Tracey and Jarvis 2007). Our study is one of the first empirical studies on social franchising. We advance the existing research on social franchising by investigating effects of the use of franchising logics in social enterprises. We offer an analysis that suggests the use of franchising logics, and particularly the use of the term "franchising," cause negative associations with strong commercially-oriented organizations. As a consequence, several stakeholders of social franchise enterprises (the general public, beneficiaries, (prospective) social franchisees, local authorities and some funders) show a strong aversion to franchising logics.

The next section of the paper briefly reviews the theoretical background on the organizational hybridity of social enterprises and on potential tensions within hybrid organizations. The third section describes our method, data collection, our sample, the interview process and the analysis of our data. The fourth section presents our findings summarized in four propositions. The final section concludes the paper and provides practical implications, as well as future research opportunities.

\section{Theoretical Background}

The fundamental mission of a social enterprise is to create social value for the public good without prioritizing financial profits over the social mission (Austin et al. 2006). In contrast, the central mission of a commercial enterprise is the realization of financial profits, resulting in private wealth. Commercial and social enterprises can therefore be distinguished based on their respective institutional logics. In this context and consistent with a growing body of research, Thornton and Ocasio (1999) define institutional logics as "the socially constructed, historical pattern of material practices, assumptions, values, beliefs, and rules by which individuals produce and reproduce their material subsistence, organize time and space, and provide meaning to their social reality." Such logics are both material and symbolic, and provide the formal and informal rules of action, interaction, and interpretation (Thornton and Ocasio 1999).

Thus, the institutional logics used in an enterprise determine the way of thinking, the decision making, and the way in which opportunities are assessed and seized. Accordingly, only two types of organizations exist. On one side, there are organizations aligned with commercial logics, which offer goods or services to obtain a financial return to serve their shareholders. On the other side, there are organizations aligned with social welfare logics, which address a social need or problem and prioritize their beneficiaries, rather than financial profits (Mair et al. 2015). It seems that these differences in logics are fundamental distinguishing features between social and commercial enterprises, but the borders between the two become blurred. Social enterprises typically incorporate parts of both commercial and social welfare logics. They adhere to social welfare logics in their goals and activities, but they have to fall back on commercial logics in order to be successful and achieve economic stability (Carroll and Stater 2009). Prior research confirms that the use of multiple logics, including commercial ones, is common for social enterprises (Austin et al. 2006; Battilana and Lee 2014; Besharov and Smith, 2014).

Due to the combination of multiple inconsistent institutional logics within one organization, these organizations do not fit neatly into established categories of conventional organizational forms, sectors, or institutional domains. For this reason, the term "hybrid organization" has been adopted to describe organizations that span institutional boundaries (Jay 2013; Pache and Santos 2013; Smith and Lewis 2011). Thus, the "not fitting" enterprises can be classified as hybrid organizations (Besharov and Smith 2014; Powell 1987). However, the definitions of what constitutes a hybrid organization vary (Mair et al. 2015).

Due to the broad definition of a hybrid organization, it is possible to identify social franchise enterprises as examples of the type. Social franchise enterprises use commercial franchising logics in a social service context. They provide goods and services to meet social needs and use institutional logics to scale their impact and achieve economic stability and sustainability. Despite their suitability for studies of hybrid organizations, there has been little research on social franchise enterprises so far. The literature is often practice-oriented and investigates challenges social entrepreneurs face in replicating social programs without even including social franchising as an option (see e.g., Ahlert et al. 2008; Bradach 2003). Even when social franchising is mentioned, it is not discussed in more detail. Existing literature focuses mainly on the scaling of social impact in general (see e.g., Bloom and Chatterji 2009; Lyon and Fernandez 2012; Wei-Skillern 2003). The only study with an exclusive focus on social franchising is the study conducted by Tracey and Jarvis (2007). Tracey and Jarvis investigate whether the resource scarcity and agency theory are applicable to social franchising, but do not mention the hybrid organizational structure of social franchises.

Recent research on hybrid organizations focuses on the analysis of tensions caused by the hybrid organizational 
structure. The significant differences between social and commercial logics illustrate the potential for tensions in hybrid organizations. Specifically, the combination of inconsistent logics might expose hybrid organizations to conflicting environmental demands (Pache and Santos 2010). The consideration of the stakeholders' interests in both fields becomes a major challenge for hybrid organizations. Moreover, addressing multiple and differing stakeholders raises questions about who and what really counts in a hybrid organization (Smith et al. 2013). Overall, prior research confirms that the combination of both logics creates internal and external tensions in hybrid organizations because satisfying institutional demands from the one side might require defying others (Dey and Teasdale 2016; Greenwood et al. 2011; Pache and Santos 2010; Smith et al. 2013). However, we know little about tensions with particular stakeholder groups, their associated challenges, and the nature of organizational responses to these tensions in social franchise enterprises. Therefore, we investigate reasons and triggers for tensions between hybrid organizations and their stakeholders and associated consequences.

\section{Method and Data}

We use an exploratory and qualitative research design, which is recommended for investigating phenomena that are poorly understood (Strauss and Corbin 1996; Yin 2009). A qualitative research design yields rich descriptions and explanations of processes, and shows contextdriven causal effects (Miles and Huberman 1994). Thus, the qualitative method allows us to understand the behavior of study participants and to build new theoretical insights.

\section{Study Setting}

Our study examines the social franchising sector. We chose to study this specific context because social franchise enterprises can be recognized as a prime example of hybrid organizations due to their integration of commercial logics (especially the logics of the commercial franchising concept) in a social entrepreneurial environment. All social franchise enterprises in our sample are located in Germanspeaking countries (Germany, Austria, and Switzerland). We chose to study social franchises in this geographical area to avoid potential biases related to cultural differences. Thus, the social franchises included in our study operate in the same cultural arena. However, it has to be mentioned that the size of our sample is limited, as the number of social franchise enterprises in German-speaking countries remains quite small. Prior research in social franchising shows similar limitations related to a small sample size (see e.g., Tracey and Jarvis 2007).

\section{Sampling Approach}

To increase the probability of collecting different and varied data, it is critical to choose a sample based on a theoretical rather than a random principle to match typical cases for the study (Strauss and Corbin 1996). According to the principles of theoretical sampling, we applied variation sampling to achieve maximum heterogeneity and chose our sample of interviewees with the need for a wide variety of cases in mind (Robinson 2014; Strauss and Corbin 1998). Thereby, we also aim to increase the probability of discovering novel, and potentially puzzling, empirical material for abductive theory development (Timmermans and Tavory 2012). To identify potential social franchises for our study, we first developed an overview of all social franchising enterprises in German-speaking countries. Following this, we chose cases that differed in their industrial area, size, maturity, and organizational structure. In total, we chose seven different social franchise enterprises. Table 1 provides an overview of all cases in our study.

Due to the need to preserve confidentiality, it is not possible to explain the cases in more detail. Owing to the small number of social franchises in Germany it would be easy to identify the social franchise enterprises in our study with the aid of a few more details. Therefore, we anonymized the cases and gave each one a number to ensure confidentiality would be maintained.

\section{Data Collection}

Having multiple sources of data is critical to qualitative research because these sources facilitate triangulation and validation of theoretical constructs (Denzin 1978). Therefore, we considered our data from different perspectives and used evidence from several sources to strengthen our study (Timmermans and Tavory 2012; Yin 2009). We gathered our data through interviews with two different target groups: (1) social franchisors and (2) their social franchisees. We applied different strategies to identify possible interviewees. For the most part, we contacted potential interview partners directly or used the recommendations of others. We solicited further recommendations by asking "Whom do you know who sees things differently?" to increase variation in our sample and discover new empirical material to potentially challenge existing theory (Miles and Huberman 1994; Tavory and Timmermans 2009). In total, we contacted more than 35 possible interviewees. In an initial round in 2016 and 2017, we conducted 14 interviews with four social franchisors 
Table 1 Sample description

\begin{tabular}{|c|c|c|c|c|c|}
\hline & Industrial area & Country & Number of franchisees & Social franchising since & Number of interviews \\
\hline Case I & Social inclusion & Germany/Austria/Switzerland & 15 & 2000 & 4 \\
\hline Case II & Education & Germany & 49 & 2009 & 4 \\
\hline Case III & Family support & Germany & 240 & 2002 & 7 \\
\hline Case IV & Refugee integration & Germany & 7 & 2016 & 1 \\
\hline Case V* & Education & Germany & - & 2002 & 1 \\
\hline Case VI & Social inclusion & Germany & 65 & 1999 & 3 \\
\hline \multirow[t]{2}{*}{ Case VII } & Family support & Germany & 62 & 2003 & 1 \\
\hline & & & \multicolumn{2}{|c|}{ Total number of interviews: } & 21 \\
\hline
\end{tabular}

*The enterprise no longer exists

and 10 social franchisees. To enlarge the sample and to deepen our preliminary findings, we conducted seven additional interviews with four social franchisors and three social franchisees in a second interview round in 2018. Most of the interviewees had at least 10 years of experience in the social sector; six had 20 years or more. Of the 21 interview partners, 14 were female. The interviewees differed in their focus area, age, and education. Table 2 summarizes the characteristics of our interviewees.

All interviewees were asked a series of open-ended questions to ensure free expression of their opinions and experiences. The open-ended questions were augmented by follow-up questions to verify and clarify the interviewees' initial answers (Spradley 1979). Additionally, scaled questions with a rank-order scale were included to enable the comparison of perceptions across different interviews. At the conclusion of the interviews, we asked the interviewees to comment on issues that were not addressed in our prior questions. This helped us to gain further unprompted insights.

We used a semi-structured guideline for the interviews. This guideline was based on previous research and guidelines for qualitative methods in organizational research (Glaser and Strauss 1967; Miles and Huberman 1994). In addition, we pre-tested the interview guideline with a social franchising expert who advises and supports social enterprises in order to detect potential misunderstandings. The interviewed expert confirmed our approach and the issues we used in our interview guideline. Only minor changes were made to the interview guideline after the pretest. The questions in our interview guideline addressed the following broad issues: (1) the experiences and background of interviewees and general information on the organization; (2) a general assessment of the social franchising concept; (3) challenges and difficulties due to the use of commercial logics in the social sector; (4) challenges and difficulties due to contractual agreements between franchisor and franchisee; and (5) relationships and difficulties between franchisor, franchisee and other stakeholders.

Of the 21 interviews, 20 were conducted by telephone and were recorded to facilitate data analysis. Only one interview was conducted by email. In this case, the interviewee responded to our request with a written answer to our main questions. The telephone interviews lasted between 44 and 99 min (66 min was the average). In total, over $22 \mathrm{~h}$ of interview data were recorded and transcribed. Following Timmermans and Tavory (2012), and Strauss and Corbin (1996), we continued to gather data until new information ceased to emerge and interviews more and more resembled the information gained in previous ones. At this point, no new insights on stakeholder perception of commercial versus social welfare logics, as well as on various associations with particular terminology and resulting tensions, emerged from conducting additional interviews. As suggested by building theory, the interviews helped us to gain new and unaffected insights into the dynamics of success and failure in the communication of social franchise enterprises. They let us observe and understand how the particular context and specific stakeholder groups' backgrounds influence the reception of logics and the relationship between social franchises and their stakeholders.

In addition to the interview data, we collected data from the written franchise agreements of the participating social franchisors. Furthermore, we examined public materials (e.g., websites) related to the enterprises whose franchisors and franchisees we interviewed. These materials helped us to acquire background information prior to an interview and to deepen and validate the data supplied by the interviewees. In particular, combining the findings from the interview data with the results from an analysis of the franchise agreements allowed us to generate a deeper understanding. 
Table 2 Characteristics of interviewees

\begin{tabular}{|c|c|c|c|c|c|c|}
\hline Type & Industrial area & Education/schooling & $\begin{array}{l}\text { Age } \\
\text { category } \\
\text { (years) }\end{array}$ & Gender & $\begin{array}{l}\text { Social sector } \\
\text { experience } \\
\text { (years) }\end{array}$ & $\begin{array}{l}\text { Length of the } \\
\text { interview } \\
\text { (minutes) }\end{array}$ \\
\hline Franchisor 1 & $\begin{array}{l}\text { Social } \\
\text { inclusion }\end{array}$ & Social pedagogy (Mag.) & $50+$ & M & $>10$ & $61: 46$ \\
\hline Franchisor 2 & Education & Communication studies (MA) & $20-30$ & $\mathrm{~F}$ & 2 & $72: 56$ \\
\hline Franchisor 3 & Family support & Political science (Dipl.) & $50+$ & $\mathrm{F}$ & $>10$ & $60: 08$ \\
\hline Franchisor 4 & $\begin{array}{l}\text { Refugee } \\
\text { integration }\end{array}$ & Cultural and music management (MA) & $30-40$ & M & 4 & $78: 11$ \\
\hline Franchisor 5 & Education & Chemistry $(\mathrm{PhD})$ & $50+$ & $\mathrm{F}$ & $>10$ & email \\
\hline Franchisor 6 & $\begin{array}{l}\text { Social } \\
\text { inclusion }\end{array}$ & Retail dealer & $50+$ & M & $>10$ & $43: 49$ \\
\hline Franchisor 7 & Family support & Political science (Dipl.) & $50+$ & $\mathrm{F}$ & $>10$ & $90: 48$ \\
\hline Franchisor 8 & Family support & $\begin{array}{l}\text { Social pedagogy (Dipl.); Business } \\
\text { administration (Dipl.) }\end{array}$ & $30-40$ & $\mathrm{~F}$ & $>10$ & $55: 31$ \\
\hline Franchisee 1 & Education & Law (Dipl.) & $20-30$ & M & 5 & $45: 40$ \\
\hline Franchisee 2 & Education & Educational science (BA) & $20-30$ & $\mathrm{~F}$ & 4 & $69: 58$ \\
\hline Franchisee 3 & Education & Law (in progress) & $20-30$ & $\mathrm{~F}$ & 3 & $85: 28$ \\
\hline Franchisee 4 & Family support & Social pedagogy (Dipl.) & $40-50$ & $\mathrm{~F}$ & $>20$ & $56: 38$ \\
\hline Franchisee 5 & Family support & Educational science (Dipl.) & $50+$ & $\mathrm{F}$ & $>20$ & $66: 41$ \\
\hline Franchisee 6 & Family support & Social pedagogy (Dipl.) & $50+$ & M & $>20$ & $98: 52$ \\
\hline Franchisee 7 & Family support & $\begin{array}{l}\text { Educational science (Dipl.); Social pedagogy } \\
\text { (Dipl.) }\end{array}$ & $40-50$ & $\mathrm{~F}$ & $>10$ & 61:07 \\
\hline Franchisee 8 & $\begin{array}{l}\text { Social } \\
\text { inclusion }\end{array}$ & Architectural studies (Dipl.) & $30-40$ & $\mathrm{~F}$ & 2 & $58: 50$ \\
\hline Franchisee 9 & $\begin{array}{l}\text { Social } \\
\text { inclusion }\end{array}$ & $\begin{array}{l}\text { Cultural, social and media studies; Social } \\
\text { pedagogy (Mag.) }\end{array}$ & $50+$ & $\mathrm{F}$ & $>20$ & $48: 39$ \\
\hline Franchisee 10 & $\begin{array}{l}\text { Social } \\
\text { inclusion }\end{array}$ & Business administration (Dipl.) & $40-50$ & $\mathrm{~F}$ & 6 & $72: 07$ \\
\hline Franchisee 11 & Family support & Social pedagogy (Dipl.) & $50+$ & $\mathrm{F}$ & $>20$ & 61:09 \\
\hline Franchisee 12 & $\begin{array}{l}\text { Social } \\
\text { inclusion }\end{array}$ & Engineer (Dipl.); Social management (Dipl.) & $40-50$ & M & $>10$ & $76: 52$ \\
\hline Franchisee 13 & $\begin{array}{l}\text { Social } \\
\text { inclusion }\end{array}$ & Technical business administration (Dipl.) & $50+$ & M & $>20$ & $64: 48$ \\
\hline
\end{tabular}

\section{Data Analysis}

As a first step, we investigated the transcribed interview data line by line to code all responses that provided relevant information, particularly similarities and differences. The coding of our data ranged from short phrases to whole paragraphs to keep the original context of the interviews. For this purpose, we worked with the qualitative data analysis software NVivo. The software helped us to find clear patterns in the transcribed interviews and the franchise agreements. In order to find similarities and differences, we used a list of codes that was based on our knowledge of prior literature and guidelines for coding and analyzing qualitative data (Miles and Huberman 1994; Saldaña 2015; Strauss and Corbin 1996; Timmermans and Tavory 2012). In the course of coding and working with the transcribed data, we continuously revisited existing concepts and simultaneously compared them with new insights from the data. Thereby, we constantly checked for new theoretical links and incessantly expanded our initial list of codes to cover all relevant aspects of the interviews (Timmermans and Tavory 2012). Afterward, we combined similar codes and discarded those that were found not to be informative for our study in order to arrive at a meaningful coding system and find convincing patterns (Gioia et al. 2013).

\section{Findings and discussion}

\section{Internal tensions caused by an imbalance of logics}

Prior research confirms that the combination of contradictory commercial and social welfare logics creates internal 
tensions within hybrid organizations because satisfying institutional demands from the one side might require defying others (Greenwood et al. 2011; Pache and Santos 2010). The involvement of different and inconsistent logics presents social enterprises with a major challenge and thereby increases the potential for tensions: these enterprises face the challenge of addressing the interests of stakeholders from both economic and social backgrounds in order to be legitimate and economically sustainable. Legitimacy is characterized as the way people subjectively believe things should be, apart from any other rational or functional calculus (Dart 2004b; Dey and Teasdale 2016). Legitimacy is an essential prerequisite for social enterprises to gain acceptance from their respective beneficiaries, funders, (prospective) social franchisees, and local authorities, and therefore also the basis for a social enterprise's economic feasibility (Dart 2004b; Nicholls 2010; Oliver 1991). At the same time, in order to be legitimate, social enterprises reportedly need to demonstrate their economic competence without failing their social objectives, which involves conforming to the expectations of stakeholders with backgrounds from both sectors (Dey and Teasdale 2016). Our interviewees confirm the balancing act between the social and the economic fields. As social franchisor \#6 stated:

It [the enterprise] is strongly designed from an economic point of view, because it has to be economically viable, there is no other way. But the [social] objective is not lost sight of, quite the opposite. I think that this remains our first objective, because that is what we are all about.

According to our data, the use of commercial logics is necessary and common in the social sector, despite the potential for tensions (see Table 3). All interviewees confirmed that requirement of commercial logics in social enterprises to be economically viable and to accomplish the social purpose in an appropriate way. Accordingly, it is common for social enterprises to avail themselves of both for-profit and non-profit institutional logics. Moreover, most of the interviewees confirmed that the involvement of commercial logics is not merely common for social enterprises, but rather a fundamental prerequisite.

Despite the fundamental necessity, our data confirm the potential for internal tensions due to low acceptance of the use of commercial logics among staff (e.g., salaried employees or volunteers) of social enterprises. Social enterprises' employees often have backgrounds in work based on social logics and, in turn, adhere to social welfare logics. The low acceptance of commercial logics by individual staff members results from a lack of understanding of the necessity to use commercial logics in order to be economically viable. These organizational members show a difficulty in comprehending hybrid organizational structures, cultures, practices, or processes. They expect solely social welfare logics in social enterprises. Consequently, they assume a mission drift due to the deviation from their "social" expectations produced by an organization's use of institutional logics. Thus, there is low acceptance of commercial logics, as social franchisee \#11 noted:

I already had a volunteer who deliberately quit after recognizing what a big institution we are. She thought it was just a small local project here in YYY. When I gave her further information material about us, she said that she didn't want to support something institutional like this. I couldn't arbitrate that in any way.

Most of our interviewees confirmed that carriers of only social welfare logics are missing a deep understanding of commercial logics. As social franchisee \#7 states:

In relation to my first profession, i.e., from the perspective of classical social pedagogy, my God, it is not always about numbers.[...]. How much have we achieved? Where are we? How many beneficiaries have we served? But this kind of work is actually about much more than that.

Furthermore, an assumed shift in organizational mission from social to commercial orientation and deviations from distinct employees' expectations of organizational structures, cultures, practices, or processes negatively influence those staff members' attitudes toward a social enterprise, and thereby decrease its legitimacy. As social franchisee \#10 puts it:

Even if it is actually called social franchise, it is not an honorary activity, not at all. Actually, I almost doubt the name social franchise. After all, it is a business; it is only coincidental that these transactions happen in the area of social welfare, in the social sector.

Thus, tensions between organizational members emerge through commitments to contradictory and conflicting commercial and social welfare logics. Furthermore, the fundamental necessity of commercial logics forces social enterprises to combine such conflicting logics within organizational structures and processes. These processes are often inconsistent, because social enterprises and business ventures frequently involve different cultures and human resource practices (Smith et al. 2013). For instance, the selection criteria of social enterprises are characterized by specific socially-oriented employee profiles: social enterprises hire employees with extensive social and interpersonal skills to ensure the fulfillment of the individual social needs of beneficiaries and customers. These employees mainly adopt social welfare logics. However, 
Table 3 Commercial logics in the social sector

\begin{tabular}{|c|c|c|c|}
\hline Construct & Group & $\begin{array}{l}\text { No. of } \\
\text { evidence }\end{array}$ & Quote \\
\hline \multirow{4}{*}{$\begin{array}{l}\text { Commercial logics are common in the } \\
\text { social sector }\end{array}$} & Total $(21)$ & 20 & \\
\hline & $\begin{array}{l}\text { Social } \\
\text { franchisors } \\
(8)\end{array}$ & 7 & Social work always has to be financed somewhere. (Social franchisor \#4) \\
\hline & $\begin{array}{l}\text { Social } \\
\text { franchisees } \\
(13)\end{array}$ & 13 & $\begin{array}{l}\text { On the other hand, however, it has to be mentioned that in the social } \\
\text { sector, you don't have to pretend that money doesn't play a role. Let's } \\
\text { be honest, that's really a bit naive. (Social franchisee \#5) }\end{array}$ \\
\hline & & & $\begin{array}{l}\text { Let me put it this way, my impression is that it [the organization] is } \\
\text { developing more and more in the direction of a business [commercial] } \\
\text { organization. With everything that entails. (Social franchisee \#6) }\end{array}$ \\
\hline \multirow{4}{*}{$\begin{array}{l}\text { Commercial logics as a prerequisite for } \\
\text { economically viable social enterprises }\end{array}$} & Total $(21)$ & 20 & \\
\hline & $\begin{array}{l}\text { Social } \\
\text { franchisors } \\
(8)\end{array}$ & 7 & $\begin{array}{l}\text { It just has to work economically, that's ultimately what's important. } \\
\text { (Social franchisor \#6) }\end{array}$ \\
\hline & \multirow{2}{*}{$\begin{array}{l}\text { Social } \\
\text { franchisees } \\
(13)\end{array}$} & \multirow[t]{2}{*}{13} & $\begin{array}{l}\text { I think you just have to be so economical that the enterprise has a chance } \\
\text { to survive. (Social franchisee \#9) }\end{array}$ \\
\hline & & & $\begin{array}{l}\text { I know that in the social sector we are perhaps more likely to say that } \\
\text { numbers are not that important. But as a franchisee, for example, we are } \\
\text { actually our own GmbH [limited liability company]. And if not in a } \\
\text { GmbH, where else I have to see that I have earned my money at the end } \\
\text { of the day [to be successful]. And that's why it's so important to us [...]. } \\
\text { (Social franchisee \#13) }\end{array}$ \\
\hline
\end{tabular}

the employment of staff with a commercial background, who are carriers of only commercial logics, is uncommon for social enterprises. Personal experiences in the social field are more important and constitute a major selection criterion in the hiring of new employees. Our data show that despite the need for organizations to use commercial logics in order to be viable, organizational members with an economic background are a minority in social enterprises. For example, it is unusual for social enterprises to have employees with a business background. As social franchisee \#10 noted,

It is frightening that I am an exception as a business person in the social sector.

According to our data, the personnel structure of social enterprises is dominated by carriers of only social welfare logics, whereas carriers of only commercial logics form a minority. As a consequence, an imbalance occurs between commercial and social welfare logics. This imbalance promotes the lack of acceptance of commercial logics by organizational members of social enterprises. It decreases the compatibility between logics and promotes tensions through conflicts due to a misunderstanding of carriers of only social welfare logics.

Our analysis of all these factors leads us to propose the following:
Pl The combination of social welfare logics and commercial logics leads to internal tensions among the social franchise enterprises' staff: The stronger the impact of social welfare logics in a hybrid organization, the higher the imbalance between logics and the lower the acceptance of commercial logics by internal stakeholders, thereby increasing the potential for tensions.

\section{The Effect of Social vs. Commercial Logics in Communicating with External Stakeholders}

External stakeholder groups (the general public, local authorities, beneficiaries, prospective and current social franchisees, and funders) vary in their perception and acceptance of a hybrid organizational structure of social enterprises.

\section{The Perception of Commercial Logics in Social Enterprises by the General Public}

Our data confirm a lack of understanding of commercial logics applied in social franchise enterprises by the general public. As social franchisee \#9 puts it:

There are always discussions with people who profess that social matters must not be economically determined. 
This is due to a lack of understanding by parts of the general public that even social enterprises have to achieve economic stability despite having a primarily socially-oriented purpose. As social franchisee \#9 explains:

It's interesting that we work for a social project but people say as an accusation that we are commercial. Just because we try to pay wages to all the people who work.[...] Because we always say that everyone who puts their energy into the project shows valuable work and that should be rewarded. Many social projects consist of volunteer engagement, but I think you have to make a living from something.

Furthermore, people may assume a mission drift because of hybrid organizational structures and the use of commercial logics in social enterprises (Carroll and Stater 2009). They suppose that wealth creation through principles from the commercial sector becomes the central task, not the accomplishment of the initial social mission. This assumption is a result of the opacity of the application of revenues. The opacity promotes information asymmetry between social enterprises and the general public: outsiders cannot comprehend how a social enterprise applies its revenues. Moreover, generating revenues is incongruent with peoples' expectations of social purpose.

Consequently, a social enterprise that integrates commercial logics suffers decreased legitimacy due to public expectations of social organizational structures and processes. In turn, a loss of legitimacy creates tensions between social enterprises and their surroundings.

Our data confirm that in order to retain legitimacy, social enterprises have to convincingly communicate that their social missions are still their central tasks, despite the attention they must devote to generating revenues. It is critical to reduce information asymmetries and legitimize the use of commercial logics. As social franchisor \#7 puts it:

We always have to prove how social our impact is. And that we really don't exploit our volunteers to earn money and let us gild [enrich] our taps in YYY and so on.

Moreover, the use of franchising logics in the social sector has a negative influence on views of the legitimacy of social enterprises. Our data suggest that franchising logics in the social sector often evoke a strong aversion. As outlined above for commercial logics in general, outsiders may assume a mission drift due to the utilization of commercial (franchising) logics. They suppose that the adoption of the franchising concept indicates a striving for financial profits, as social franchisor \#1 emphasized:
Franchising is rooted in people's minds with large companies, standardization and profit making. And that is something that is so frowned upon in the social sector. In other words, if you offer social services, you don't do it to gain profits. You don't want to generate profits [with the franchising concept], but the internal philosophy of the enterprise and the image to the outside world are different.

Our data confirm that people not directly involved in the social franchise enterprises' management and operation may assume a mission drift when there is a visible integration of franchise principles in a social enterprise. They suppose that wealth creation, not the accomplishment of the social mission, becomes the central task of a social franchise enterprise. As social franchisor \#1 stressed,

$[\ldots]$ a possible assumption is that we are an enterprise that wants to gain financial profits in the social field. And this association appears relatively quickly in people's minds.

This assumed mission drift is due to an association of the franchising concept with only strong commerciallyoriented enterprises, for example with business organizations within the food industry.

Beyond that, people show negative associations with the franchising concept in general. Independently from the social sector, franchising has a lost reputation, as social franchisor \#6 noted: "Franchising is always a bit negative, because franchising has not necessarily enjoyed the best reputation in the past." Negative examples (e.g., within the fast food industry) defile the concept's reputation and decrease acceptance of the concept by society. Within our sample, our data confirm a loss in reputation of the franchising concept in general and a lack of acceptance of the concept by the general public. Most of our interviewees reported experiences in which the franchising concept was perceived negatively due to a comparison with negative examples of the commercial food industry.

Consequently, the assumed drift in mission and the lack of acceptance of franchising logics by the general public due to negative associations lead to a strong aversion for franchising logics in the social sector. As social franchisor \#4 states:

I'm very hesitant because in the context of the social sector, you also alienate a lot of people when you say that you operate a social franchise system. That's why we never use the term 'franchising' $[\ldots]$.

This, in turn, decreases the legitimacy of social enterprises that use franchise logics, and the potential for tensions increases. Our interviewees stressed that in particular the use of the term "franchising" in connection with a 
social organization has a negative influence on the legitimacy of a social franchise enterprise. The distinct usage of the term creates tensions through negative reactions.

In summary, our data demonstrate that the combination of social welfare and commercial logics can create tensions between social enterprises and their surroundings. Parts of the general public fail to understand the necessity of commercial instruments in ensuring the viability of social enterprises. The use of the term "franchising" particularly causes negative reactions and tensions, thereby decreasing the legitimacy of the social franchise enterprise. Overall, we formulate the following proposition:

$P 2$ The use of commercial terminology in general, and franchising in particular, leads to tensions in communication with the general public. The more commercial terms are used to describe the hybrid structure of an organization, the lower the legitimacy of the organization in the eyes of the general public, thereby increasing the potential for tensions.

\section{Specific External Stakeholder Groups and Their Individual Perception of Commercial Logics in Social Franchising Enterprises}

Beneficiaries Most of our interviewees confirmed that receiving payments for social services leads to conflicts with beneficiaries of social enterprises. As social franchisee \#8 stated, these beneficiaries are not able to comprehend the use of commercial logics in order to cover expenses and efforts of social enterprises:

For example, if we say that our service costs 300 euros, then that is incomprehensible to them [beneficiaries]. They don't understand that our service costs money. Because that's a lot of money for them, but that there is a benefit behind it, and that we [the enterprise] make an effort, that's sometimes not seen by them.

According to our interviewees, there is a widespread mentality that social services must be free of charge. As social franchisee \#8 confirms:

And what I actually find much more important is the fact that regarding the services that we offer, that sometimes it is outrageous that money is earned or that it [our service] costs something. And that is a much bigger issue, especially in the field in which we are active. Because there, unlike the free economy, the money is usually not so loose.[People cannot afford the service] But those are the people who really need it. And that is such a difficulty. [...] So our colleagues [in the commercial sector] get paid for what they do. And we also pay our people to do the work. So I never understand how you can shake your head and wonder why it costs anything.

As outlined above, misunderstandings can be traced back to the opacity of the revenues' application within the social enterprise. This information asymmetry inhibits the traceability of revenues and their reinvestment within the social enterprise, and thereby prevents beneficiaries' recognition of the importance of revenue for the social enterprise's economic sustainability. The fact that prices are charged for social (franchise) enterprises' products or services causes beneficiaries to suspect a mission drift. In line with our previous findings, beneficiaries react negatively to assumed mission drift caused by commercial logics. Due to this deviation from beneficiaries' expectations, the social enterprise's legitimacy decreases.

(Prospective) Social Franchisees In addition to our findings concerning beneficiaries, our data reveal that prospective social franchisees find it difficult to accept that franchising fees are charged. The experience of social franchisor \#8 illustrates the issue:

People think that if you want to help everyone, then you have to help among each other and you have an obligation to pass on your acquired know-how for free. I also have a commitment to my own employees that they get paid now and in the future. And they only get paid if I get paid for what we pass on.

She further explains:

There are very big problems with the attitude that you can't take money for passing on an idea [a franchising concept] in the social sector. In other words, that we simply get paid for the knowledge and know-how that has grown in our enterprise and that we pass on. Because the development of know-how has to come from somewhere and has to be paid for by us. That's just difficult.[...] and that's why there's not always the willingness or understanding in the social sector that you have to pay for services.

Once again, the revelation of the fact that fees are charged from social franchisees constitutes a deviation from prospective social franchisees' expectations toward a social franchise scheme. Prospective social franchisees' unawareness of the rationale and economic necessity to charge franchising fees constitutes an information asymmetry. The negative connotation of franchising, paired with the unanticipated application of commercial logics in the social welfare context, leads to alienation and decreased legitimacy of the social franchise enterprise in the eyes of prospective social franchisees. 
We know from previous research on the topic that current social franchisees also react sensitively to any increase in social franchise fees charged by social franchisors (Bergfeld et al. 2020).

Local Authorities Local authorities, or local government, respectively, are responsible for a range of services to people and businesses, and therefore they are important stakeholders for social enterprises. They are responsible for local support to social enterprises and might embed their activities into community development programs, for example. In some cases, local authorities play a vital role in creating demand for social enterprises' output, for instance by limiting government sourcing to social enterprises. Furthermore, they are responsible for determining taxable and non-taxable commercial activities, which renders local authorities fundamentally important for social enterprises' economic situation (Borzaga and Defourny 2001; Kerlin 2006)

In line with previous results for other stakeholder groups, the use of commercial logics, and franchising terminology in particular, seems to evoke the perception of mission drift by local authorities. As social franchisor \#3 states:

A lot of partners [franchisees] tell us that they use the term 'social franchise' very sparingly because, for example, local authorities can't associate anything social with it.

The term "franchising" seems to evoke negative associations from the staff of local authorities, just as with the general public. The information asymmetry among social (franchise) enterprises and local authorities, however, should be less pronounced than for the general public, as local authorities' set of responsibilities (like the determination of taxable and non-taxable activities) comprises the detailed analysis of social enterprises' "business" models. In fact, a potentially inaccurate first impression caused by the use of franchising terminology might be rectified upon closer inspection.

Funders The evidence of the perception of social versus commercial logics among funders of social franchise enterprises is mixed. Franchisor \#7 made the experience that stressing social logics was important for potential funders:

And that [proving how social our impact is] always brought us the respect and especially [financial] support in an early stage.

Franchisor \#3, on the other hand, found that a funder was particularly convinced by commercial logics and the scaling potential implied by the application of franchising to the social welfare sector:

So in our case there were definitely positive effects, because from 2009 we had the support of [a funder] who said decidedly: We support you because we want to promote the scaling, the multiplication. In fact, they were very keen on that [commercial terminology].

Apparently, the perception of commercial logics in social (franchise) enterprises by funders differs greatly. Whether the use of commercial logics is perceived well or not might depend on the particular funder's background. As outlined above, the sources of funds are very diverse and broader for social enterprises than for purely commercial ones. That includes sources of finance that also available to commercial ventures, as well as sources which are exclusively tailored to the social, or social enterprise, sector. As the information asymmetry between social (franchise) enterprises and their funders is expected to be rather small, as funders are usually granted thorough information about the "business" model, we expect the funders' (more social versus more commercial) background to play a central role in whether they react positively or negatively to commercial logics.

Analyzing the perception of commercial vs. social welfare logics for various stakeholder groups individually, we find that commercial logics in general, and franchising terminology in particular, evoke negative reactions from many, but not all stakeholder groups. The negative reaction is caused by a deviation from the particular stakeholder's expectation toward a social (franchise) enterprise, which might lead to a perceived mission drift. This deviation of expectation from reality is potentially related to the stakeholders' own (more social vs. more commercial) background, and aggravated by information asymmetries among social (franchise) enterprises and their stakeholders. Information on the "business" model and acquaintance with the social enterprise's cash flows and operations can help reduce the information asymmetry. We therefore formulate the following proposition:

P3 The combination of social welfare logics and commercial logics can lead to tensions between the social (franchise) enterprise and external stakeholders (beneficiaries, (prospective) social franchisees, local authorities, and funders). The more commercially oriented the stakeholders' background and the lower the information asymmetry between a hybrid organization and a respective group of external stakeholders, the higher the legitimacy of the combination of commercial with social welfare logics in the eyes of the respective stakeholder, and the lower the potential for tensions. 


\section{The Use of Social vs. Commercial Logics in Social Franchise Enterprises' Communication with External Stakeholders}

The negative perception of commercial logics and franchising terminology among many stakeholders of social franchise enterprises requires conscious communication and deliberate wording depending on the respective stakeholder group.

According to our data, social franchisors and social franchisees avoid the term "franchising." As social franchisor \#8 noted:

We use the term very, very, very rarely in our context. Because, in the social context, there are challenges with the franchising term, with economic terms in general. In general, such things can quickly cause strange reactions. And that doesn't make it any easier for us to grow. So because winning new cooperation partners or franchisees is incredibly hard.

And the term franchise makes it even more challenging. [...] So we really don't use it much.

Most of our interviewees confirmed an avoidance of the term "franchising" in order to evade tensions. Only two interviewees of our sample indicated that they did not strictly avoid the term. They stated that they use the term deliberately but sparingly (see Table 4).

Instead of using the term franchising, social franchisors and social franchisees consciously use substitute terms that do not refer to the franchising concept, in order to avoid negative associations (see Table 4). For instance, they use terms like "cooperation" or "partnering" to explain the organizational structures and processes and to express the relationship between social franchisors and social franchisees. As social franchisee \#13 noted,

And if you present yourself as a cooperation partner [instead of a franchisee], then it is more tangible for everyone without any conflicts.

Due to the avoidance of commercial terms and the use of substitute "social fitting" terms, the potential for tensions decreases. In this way, social franchise enterprises avoid conflicts and a decreasing legitimacy.

The analysis of the franchise agreements confirmed our finding that social franchise enterprises deliberately avoid using the term "franchise" to describe the concept. Four out of five franchise agreements do not contain the term "franchise." Only one social franchisor uses it excessively in his contract. All other social franchisors use terms like cooperation, partnering, or licensing to describe the concept and organizational structures and to express the relation between the social franchisor and the social franchisees (Table 5).
In summary, we theorize from our data that the use of commercial terms in the social sector creates tensions between social enterprises and many of their stakeholder groups (staff, the general public, beneficiaries, (prospective) social franchisees, local authorities, and funders). While there are some exceptions (some funders reportedly reacted positively to franchising), many stakeholders assume a mission drift due to the use of franchising logics. Primarily, they assume that wealth creation through franchise principles, not the accomplishment of the social mission, is the central task of a social franchise enterprise. Assumptions about mission drift and the lack of acceptance of franchising logics due to negative associations with the franchising concept lead to a strong aversion to franchising logics by many stakeholder groups. This, in turn, promotes an avoidance of the term "franchising" on the part of social franchise enterprises. Thus, social franchise enterprises deliberately use substitute terms instead to describe organizational structures and processes. The avoidance of the term "franchising" and the use of substitute words increase the legitimacy of a social franchise enterprise and reduce the potential for tensions with many stakeholder groups. However, our data also show that there are some stakeholders who react positively to commercial (franchising) logics. The avoidance of commercial (franchising) terminology in communication with these counterparts is unfavorable for social franchise enterprises. We therefore formulate the following propositions:

$P 4 a$ Hybrid organizations like social franchise enterprises ponder the use of social welfare vs. commercial logics carefully in their communication with various external stakeholder groups.

$P 4 b$ Synonyms for commercial terminology are commonly applied in the social (franchise) sector to prevent negative reactions.

\section{Conclusion}

The aim of our study is to examine whether and how tensions stemming from the interplay of commercial versus social welfare logics in hybrid organizations arise between social enterprises and their stakeholders. We shed light on tensions in hybrid organizations, their associated challenges, and the nature of organizational responses to these tensions. We followed a qualitative research approach to take into account the whole context of the relations between hybrid organizations and their stakeholders. We found evidence that a social welfare-oriented personnel structure in hybrid organizations promotes an imbalance between social welfare and commercial logics and 
Table 4 Handling potential tensions caused by conflicting logics in practice

\begin{tabular}{|c|c|c|c|}
\hline Construct & Group & $\begin{array}{l}\text { No. of } \\
\text { evidence }\end{array}$ & Quote \\
\hline \multirow{3}{*}{$\begin{array}{l}\text { Avoidance of the term } \\
\text { 'franchising' }\end{array}$} & Total (21) & 12 & \\
\hline & $\begin{array}{l}\text { Social } \\
\text { franchisors } \\
(8)\end{array}$ & 5 & $\begin{array}{l}{[\ldots] \text { I have really avoided the vocabulary for many years. Also in the documents }} \\
\text { we presented. (Social franchisor \#7) }\end{array}$ \\
\hline & $\begin{array}{l}\text { Social } \\
\text { franchisees } \\
(13)\end{array}$ & 7 & $\begin{array}{l}\text { I've never used the term 'social franchise' before.[...] Franchising always sounds } \\
\text { like a chain, with no individuality and no personality of its own.[...] That's why } \\
\text { we say that we have a gGmbH [non-profit limited liability company], but we } \\
\text { don't use the word 'social franchise'. (Social franchisee \#3) }\end{array}$ \\
\hline \multirow{4}{*}{$\begin{array}{l}\text { Sparing and considered use of } \\
\text { the term 'franchising' }\end{array}$} & Total (21) & 3 & \\
\hline & $\begin{array}{l}\text { Social } \\
\text { franchisors }\end{array}$ & 2 & $\begin{array}{l}\text { But we dare to talk about franchising. And the trust in a working concept gives us } \\
\text { the courage to explain it publicly. (Social franchisor \#1) }\end{array}$ \\
\hline & (8) & & $\begin{array}{l}\text { I can still remember a colleague who very offensively incorporated the term } \\
\text { 'franchising' into her presentation at a symposium. And that was a courageous } \\
\text { step. Because the first thought about franchising is another [negative } \\
\text { association]. (Social franchisor \#1) }\end{array}$ \\
\hline & $\begin{array}{l}\text { Social } \\
\text { franchisees } \\
(13)\end{array}$ & 1 & $\begin{array}{l}\text { So I'm using it [the term franchising] consciously, but purposefully.(Social } \\
\text { franchisee \#5) }\end{array}$ \\
\hline \multirow{4}{*}{$\begin{array}{l}\text { Cooperation as an alternative } \\
\text { wording }\end{array}$} & Total (21) & 8 & \\
\hline & $\begin{array}{l}\text { Social } \\
\text { franchisors } \\
(8)\end{array}$ & 5 & $\begin{array}{l}\text { I used to say that it's just a kind of a franchise. That has always helped a little bit. } \\
\text { And I called it cooperation. And our contracts are not called franchise contracts } \\
\text { either, but rather cooperation agreements. (Social franchisor \#3) }\end{array}$ \\
\hline & & & $\begin{array}{l}\text { So we call our franchisees cooperation partners. We conclude a cooperation } \\
\text { agreement in which it is defined who has what obligations and rights. So we call } \\
\text { it cooperation. (Social franchisor \#8) }\end{array}$ \\
\hline & $\begin{array}{l}\text { Social } \\
\text { franchisees } \\
\text { (13) }\end{array}$ & 3 & $\begin{array}{l}\text { I'd rather avoid the term [franchising]. So I think it's more of a cooperation. That's } \\
\text { it. (Social franchisee \#13) }\end{array}$ \\
\hline
\end{tabular}

Table 5 Terminology in franchise agreements

\begin{tabular}{llll}
\hline Source & $\begin{array}{l}\text { Distinct usage of } \\
\text { franchise terminology* }\end{array}$ & $\begin{array}{l}\text { Avoidance of franchise } \\
\text { terminology* }\end{array}$ & $\begin{array}{c}\text { Alternative terminology used } \\
\text { in the franchise agreement }\end{array}$ \\
\hline Franchise agreement \#1 & $\mathrm{x}(276)$ & $\mathrm{x}(0)$ & cooperation \\
Franchise agreement \#2 & & $\mathrm{x}(0)$ & cooperation \\
Franchise agreement \#3 & & $\mathrm{x}(0)$ & cooperation, licensing \\
Franchise agreement \#4 & & $\mathrm{x}(0)$ & cooperation, partner \\
Franchise agreement \#5 & &
\end{tabular}

*Frequency of term usage put in parentheses

increases a lack of acceptance of commercial logics by organizational members. The logic imbalance in turn increases the potential for internal tensions. Future research will need to further explore targeted internal communication and employee education, as well as hiring policies that social enterprises may adopt to cope with the demands imposed by the social welfare and commercial logics that they combine.
Furthermore, we found evidence that an information asymmetry between social enterprises and external stakeholders (the general public, beneficiaries, (prospective) social franchisees, local authorities, and funders) can promote a lack of acceptance of commercial logics by these stakeholders. Besides information asymmetries, a particular stakeholder's background and preferences might play a role in their perception of commercial logics. Stakeholders' reactions, however, are not negative throughout. Some 
funders reportedly reacted positively to commercial logics applied in the context of social franchise enterprises.

Among those stakeholders that react negatively, we found evidence that these are likely to assume a mission drift due to the use of commercial terms to describe organizational structures in the social sector. Their lack of acceptance of commercial logics decreases the legitimacy of a hybrid organization and increases the potential for tensions. This, in turn, promotes avoidance of commercial terms on the part of the hybrid organizations, despite using the underlying mechanisms. The avoidance of commercial terms and the use of substitute words can help retain the legitimacy of a hybrid organization and reduce the potential for tensions. As some stakeholders react positively to commercial logics in social franchise enterprises, a conscious application of commercial versus social welfare terminology helps tailor communication to specific counterparts and therefore prevent tensions and misunderstandings.

In summary, we theorize from our data that social enterprises deliberately use commercial, social welfare, and alternative terminology depending on individual counterparts and the intended effect in order to be legitimate and to prevent tensions. That is in line with previous results of Dey and Teasdale (2016), who found that third sector organizations in the UK not only consciously use particular terminology tailored to their counterparts, but reportedly disguise themselves as "commercial" in order to tap funds that way.

Our study has some limitations. Mainly, our study setting constrains the generalizability of our findings due to the specific focus on social franchise enterprises. On the one hand, the specific context of social franchises leads to a relatively small population and sample size, as shown in the third section of our study. However, despite the small sample size, we gained theoretical saturation in our qualitative analysis, which we detected once the interviewees' statements on stakeholders' perception of commercial versus social welfare terminology became repetitive and stopped delivering new insights. On the other hand, the form of social franchise organizations might be an extreme form of hybridity and could lead to distortions in our findings. Thus, our conclusions cannot be generalized to the hybrid organizational context due to the specifics of social franchise cases. More research is needed to further differentiate stakeholders' reactions to commercial versus social welfare logics in social enterprises, and investigate potential causes of those reactions, like their background and previous experience. Moreover, some of our findings may be limited to the specific context of German-speaking countries and may not necessarily apply to other countries. For instance, it is conceivable that the franchising concept could enjoy a better reputation in the USA due to the historical origin of franchising and a wider spread. Thus, future research is needed to investigate differences or similarities between different cultural areas or countries.

Several practical implications can be drawn from our study to reduce potential tensions with stakeholders of social franchise enterprises and hybrid organizations in general. Our results underline the relevance of a high level of transparency of the usage of gained revenues in the social sector, and especially so in social franchising enterprises, as franchising is negatively connotated over and above being a "commercial" term. Social franchise enterprises should actively communicate the detailed usage of the revenues to emphasize the actual benefit for stakeholders of the enterprise and to reduce information asymmetries. It is critical to emphasize the social purpose of the social franchise enterprise and to very consciously use commercial versus social welfare logics in communication with particular stakeholders. Furthermore, hiring members who are carriers of commercial logics in social enterprises can increase the logic compatibility and reduce the potential for tensions. Social franchise enterprises could acquire carriers of commercial knowledge and socialize them to adhere to an integrated mission incorporating both commercial logics and the organization's social welfare logics. This would adjust imbalances in the personnel structure and increase the logic compatibility, compared to the practice of hiring members with only social welfare logics.

Finally, our results highlight the importance of consciously communicating with particular counterparts, as various stakeholder groups react differently to commercial (franchise) terminology used in social franchise enterprises. Tailoring communication to specific stakeholders retains legitimacy and reduces the potential for avoidable tensions.

Funding Open Access funding enabled and organized by Projekt DEAL.

Open Access This article is licensed under a Creative Commons Attribution 4.0 International License, which permits use, sharing, adaptation, distribution and reproduction in any medium or format, as long as you give appropriate credit to the original author(s) and the source, provide a link to the Creative Commons licence, and indicate if changes were made. The images or other third party material in this article are included in the article's Creative Commons licence, unless indicated otherwise in a credit line to the material. If material is not included in the article's Creative Commons licence and your intended use is not permitted by statutory regulation or exceeds the permitted use, you will need to obtain permission directly from the copyright holder. To view a copy of this licence, visit http://creativecommons. org/licenses/by/4.0/. 


\section{References}

Ahlert, D., Ahlert, M., Dinh, H. V. D., Fleisch, H., Heußler, T., Kilee, L., \& Meuter, J. (2008). Social franchising: A way of systematic replication to increase social impact; practical guidelines, case studies, checklists. Berlin: Bundesverband Deutscher Stiftungen.

Austin, J., Stevenson, H., \& Wei-Skillern, J. (2006). Social and commercial entrepreneurship: Same, different, or both? Entrepreneurship Theory and Practice, 30(1), 1-22.

Battilana, J., \& Dorado, S. (2010). Building sustainable hybrid organizations: The case of commercial microfinance organizations. Academy of Management Journal, 53(6), 1419-1440. https://doi.org/10.5465/amj.2010.57318391

Battilana, J., \& Lee, M. (2014). Advancing research on hybrid organizing-insights from the study of social enterprises. The Academy of Management Annals, 8(1), 397-441. https://doi.org/ $10.1080 / 19416520.2014 .893615$

Beckmann, M., \& Zeyen, A. (2013). franchising as a strategy for combining small and large group advantages (Logics) in social entrepreneurship. Nonprofit and Voluntary Sector Quarterly, 43(3), 502-522. https://doi.org/10.1177/0899764012470758

Beckmann, M., \& Zeyen, A. (2014). Franchising as a strategy for combining small and large group advantages (logics) in social entrepreneurship: A hayekian perspective. Nonprofit and Voluntary Sector Quarterly, 43(3), 502-522.

Bergfeld, A., Lutz, E., \& Scheck, B. (2020). Social franchising: A transitional solution for organisational growth of social entrepreneurial organisations? International Journal of Entrepreneurial Venturing, 12(1), 17-38.

Besharov, M. L., \& Smith, W. K. (2014). Multiple institutional logics in organizations: Explaining their varied nature and implications. Academy of Management Review, 39(3), 364-381. https://doi. org/10.5465/amr.2011.0431

Bloom, P. N., \& Chatterji, A. K. (2009). Scaling social entrepreneurial impact. California Management Review, 51(3), 114-133. https://doi.org/10.2307/41166496

Borzaga, C., \& Defourny, J. (Eds.) (2001). Conclusions: Social enterprises in Europe: A diversity of initiatives and prospects. In The emergence of social enterprise (pp. 350-370). London, New York: Routledge.

Bradach, J. L. (2003). Going to scale: The challenge of replicating social programs. Stanford Social Innovation Review, 1(1), $18-23$.

Bull, M. (2008). Challenging tensions: critical, theoretical and empirical perspectives on social enterprise. International Journal of Entrepreneurial Behavior \& Research, 14(5), 268-275.

Carroll, D. A., \& Stater, K. J. (2009). Revenue diversification in nonprofit organizations: Does it lead to financial stability? Journal of Public Administration Research and Theory, 19(4), 947-966. https://doi.org/10.1093/jopart/mun025

Dacin, M. T., Dacin, P. A., \& Tracey, P. (2011). Social entrepreneurship: A critique and future directions. Organization Science, 22(5), 1203-1213. https://doi.org/10.1287/orsc.1100.0620

Dart, R. (2004a). Being "business-like" in a nonprofit organization: A grounded and inductive typology. Nonprofit and Voluntary Sector Quarterly, 33(2), 290-310.

Dart, R. (2004b). The legitimacy of social enterprise. Nonprofit management and leadership, 14(4), 411-424.

Defourny, J., \& Nyssens, M. (2010a). Conceptions of social enterprise and social entrepreneurship in Europe and the United States: Convergences and divergences. Journal of social entrepreneurship, 1(1), 32-53.

Defourny, J., \& Nyssens, M. (2010b). Social enterprise in Europe: At the crossroads of market, public policies and third sector. Policy and society, 29(3), 231-242.
Defourny, J., \& Nyssens, M. (2017). Fundamentals for an international typology of social enterprise models. VOLUNTAS: International Journal of Voluntary and Nonprofit Organizations, 28(6), 2469-2497.

Denzin, N. K. (1978). The research act: The interrelationship of theory and method. In J. G. Manis \& B. N. Meltzer (Eds.), Symbolic interaction: A reader in social psychology (3rd ed., pp. 56-68). Boston, MA: Allyn and Bacon.

Dey, P., \& Teasdale, S. (2016). The tactical mimicry of social enterprise strategies: Acting 'as if'in the everyday life of third sector organizations. Organization, 23(4), 485-504.

Doherty, B., Haugh, H., \& Lyon, F. (2014). Social enterprises as hybrid organizations: A review and research agenda. International Journal of Management Reviews, 16(4), 417-436.

Gioia, D. A., Corley, K. G., \& Hamilton, A. L. (2013). Seeking qualitative rigor in inductive research: Notes on the gioia methodology. Organizational Research Methods, 16(1), 15-31. https://doi.org/10.1177/1094428112452151

Glaser, B. G., \& Strauss, A. L. (1967). The discovery of grounded theory: Strategies for qualitative research. Chicago: Aldine.

Grant, S. (2014). Social enterprise through a critical appreciative lens. In Denny, S. \& Seddon, F. (Eds.), Social Enterprise: Accountability and evaluation around the world (pp. 213-230). Oxon, New York: Routledge.

Greenwood, R., Raynard, M., Kodeih, F., Micelotta, E. R., \& Lounsbury, M. (2011). Institutional complexity and organizational responses. Academy of Management Annals, 5(1), 317-371. https://doi.org/10.5465/19416520.2011.590299

Jay, J. (2013). Navigating paradox as a mechanism of change and innovation in hybrid organizations. Academy of Management Journal, 56(1), 137-159.

Kerlin, J. A. (2006). Social enterprise in the United States and Europe: Understanding and learning from the differences. VOLUNTAS: International Journal of Voluntary and Nonprofit Organizations, 17(3), 246.

Kistruck, G. M., Webb, J. W., Sutter, C. J., \& Ireland, R. D. (2011). Microfranchising in base-of-the-pyramid markets: Institutional challenges and adaptations to the franchise model. Entrepreneurship Theory and Practice, 35(3), 503-531.

Lyon, F., \& Fernandez, H. (2012). Strategies for scaling up social enterprise: Lessons from early years providers. Social Enterprise Journal, 8(1), 63-77.

Mair, J., Mayer, J., \& Lutz, E. (2015). Navigating institutional plurality: Organizational governance in hybrid organizations. Organization Studies, 36(6), 713-739. https://doi.org/10.1177/ 0170840615580007

Miles, M. B., \& Huberman, A. M. (1994). Qualitative data analysis: An expanded sourcebook. Thousand Oaks: Sage.

Nicholls, A. (2010). The legitimacy of social entrepreneurship: reflexive isomorphism in a pre-paradigmatic field. Entrepreneurship Theory and Practice, 34(4), 611-633. https://doi.org/10. 1111/j.1540-6520.2010.00397.x

Oliver, C. (1991). Strategic responses to institutional processes. Academy of Management Review, 16(1), 145-179.

Pache, A.-C., \& Santos, F. (2010). When worlds collide: the internal dynamics of organizational responses to conflicting institutional demands. Academy of Management Review, 35(3), 455-476. https://doi.org/10.5465/amr.35.3.zok455

Pache, A.-C., \& Santos, F. (2013). Inside the hybrid organization: Selective coupling as a response to competing institutional logics. Academy of Management Journal, 56(4), 972-1001.

Parkinson, C., \& Howorth, C. (2008). The language of social entrepreneurs. Entrepreneurship and Regional Development, 20(3), 285-309. 
Powell, W. W. (1987). Hybrid organizational arrangements: new form or transitional development? California Management Review, 30(1), 67-87. https://doi.org/10.2307/41165267

Robinson, O. C. (2014). Sampling in interview-based qualitative research: A theoretical and practical guide. Qualitative Research in Psychology, 11(1), 25-41.

Saldaña, J. (2015). The coding manual for qualitative researchers. Thousand Oaks: Sage.

Seanor, P., \& Meaton, J. (2007). Making sense of social enterprise. Social Enterprise Journal, 3(1), 90-100.

Smith, W. K., Gonin, M., \& Besharov, M. L. (2013). Managing social-business tensions: A review and research agenda for social enterprise. Business Ethics Quarterly, 23(3), 407-442. https:// doi.org/10.5840/beq201323327

Smith, W. K., \& Lewis, M. W. (2011). Toward a theory of paradox: A dynamic equilibrium model of organizing. Academy of Management Review, 36(2), 381-403. https://doi.org/10.5465/amr. 2009.0223

Spradley, J. (1979). The ethnographic interview. New York: Holt, Rinehart and Winston.

Strauss, A., \& Corbin, J. (1996). Grounded theory: Grundlagen qualitativer sozialforschung. Weinheim: Psychologie-VerlagsUnion.

Strauss, A., \& Corbin, J. (1998). Basics of qualitative research techniques. Thousand Oaks, CA: Sage Publications.

Tavory, I., \& Timmermans, S. (2009). Two cases of ethnography: Grounded theory and the extended case method. Ethnography, $10(3), 243-263$.
Teasdale, S. (2012). Negotiating tensions: how do social enterprises in the homelessness field balance social and commercial considerations? Housing Studies, 27(4), 514-532.

Thornton, P. H., \& Ocasio, W. (1999). Institutional logics and the historical contingency of power in organizations: Executive succession in the higher education publishing industry, 1958-1990. American Journal of Sociology, 105(3), 801-843. https://doi.org/10.1086/210361

Timmermans, S., \& Tavory, I. (2012). Theory construction in qualitative research: From grounded theory to abductive analysis. Sociological Theory, 30(3), 167-186.

Tracey, P., \& Jarvis, O. (2007). Toward a theory of social venture franchising. Entrepreneurship Theory and Practice, 31(5), 667-685. https://doi.org/10.1111/j.1540-6520.2007.00194.x

Volery, T., \& Hackl, V. (2010). The promise of social franchising as a model to achieve social goals. In A. Fayolle \& H. Matlay (Eds.), Handbook of research on social entrepreneurship (pp. 155-179). UK: Cheltenham.

Wei-Skillern, J. (2003). Nonprofit geographic expansion: Branches, affiliates, or both? CASE working paper series No. 4. Working paper. Division of Research, Harvard Business School. Cambridge.

Yin, R. K. (2009). Case study research: Design and methods (4th ed.). Thousand Oaks: Sage.

Publisher's Note Springer Nature remains neutral with regard to jurisdictional claims in published maps and institutional affiliations. 